\title{
Monograph Review
}

\section{HUMAN CAPITAL OF POLISH AND UKRAINIAN ENTERPRISES IN THE VOLATILE ECONOMIC ENVIRONMENT}

(Original title: ЧЕЛОВЕЧЕСКИЙ КАПИТАЛ ПОЛЬСКИХ И УКРАИНСКИХ ПРЕДПРИЯТИИ В УСЛОВИЯХ ИЗМЕНЧИВОЙ ЭКОНОМИЧЕСКОЙ СРЕДЫ)

\author{
by author Ludmila Stemplewska
}

Received: 29 June 2020; Published: 11 July 2020

The monograph HUMAN CAPITAL OF POLISH AND UKRAINIAN ENTERPRISES IN THE VOLATILE ECONOMIC ENVIRONMENT (Original title: ЧЕЛОВЕЧЕСКИЙ КАПИТАЛ ПОЛЬСКИХ И УКРАИНСКИХ ПРЕДПРИЯТИИ В УСЛОВИЯХ ИЗМЕНЧИВОЙ ЭКОНОМИЧЕСКОЙ СРЕДЫ) submitted for review is an interesting and valuable study which in a complex and in-depth manner deals with the question of human capital in the Polish and Ukrainian enterprises in a setting of volatile economic environment.

The monograph comprises a unique and creative achievement of the author and has a considerable impact on the state of knowledge and directions of further research on the influence of various factors on the level of human capital development in Poland and Ukraine. One interesting example is drawing attention to the impact of environmental factors on the development of human capital and establishing those having the greatest effect.

The theoretical portion of the monograph testifies to a very good substantive preparation, knowledge in the field of management and economics. A substantial part of the research is constituted by the analysis presenting the development trend of Poland and Ukraine based on economic data, thus showing the similarities and differences. Another substantial portion of the study is the inclusion of advanced research methods to obtain a model solution in the scope of:

- Assessment of the priorities of criteria for evaluating human development indicators.

- Selection of essential indicators from the set of all presented in the report "The Indices and Indicators of Human Development". 
- Assessment of selected indicators of the impact on the social, economic and innovative development of enterprises and the country.

It is an original concept that certainly reflects the high quality of the research.

It should be emphasized that the presented monograph combines three aspects: theoretical, empirical and applicative. The theoretical aspect includes an extensive analysis of the source literature. The empirical portion concerns the analysis of the obtained results related to the influence of various factors on the level of human capital development in Poland and Ukraine, with the help of knowledge, attitudes and opinions obtained both as a result of basic research, as well as due to research of respondents, and the application of $\mathrm{T}$. Saati's system analysis of relative importance (meaning, advantages).

The monograph concerns the presented problem identification, appearing during implementation of managing employee development, and providing information, supplementing the previous experiences and helping to limit the number of errors in making decisions streamlining the management of employee development.

In my opinion, the academic quality is very high, which is proven by the following arguments, of which I shall recall a few:

1. The monograph contains the results of extensive scientific research, interesting, unique and inspiring to deepen studies towards determining the level of impact of various factors on human capital development not only in Poland and Ukraine, but also in other countries during 4.0 and COV 19.

2. The applicative dimension of this type of research has been clearly indicated, which allows us to expand our knowledge in the field of management and economics.

3. The research is perfectly embedded in the academic literature of domestic and foreign authors of scientific studies. This is reflected not just by the bibliography which contains over 300 sources of periodical and condensed nature, but also the creative use of the content of those publications in own theorems and explanations. The study fully reflects and summarizes the scientific achievements in the field of scientific interest.

4. The monograph was structured correctly in terms of methodology, and the results were discussed and analyzed with a high level of scientific competence.

5. The paper presents an innovative issue which is certainly a very valuable perspective at the issues concerning the level of influence of various factors on human capital development in Poland and Ukraine.

6. The high quality of the monograph is also reflected in the structured, logical and consistent arguments. The division into chapters and sub-chapters is correct, appropriate proportions, and the method of presenting analyses and thoughts is transparent and uses the accepted terminology. Owing to this, the study and its contents are easily understandable. 
Summarizing the previous comments and partial classification, I would like to state that the submitted monograph has all the features of an innovative scientific research, prepared with the utmost care for the quality of scientific works. It comprises a unique and creative achievement of the Author and will have a considerable impact on the state of knowledge and the directions of further research in the scope regarding the level of impact of various factors on the development of human capital in Poland and Ukraine. The monograph is useful for scientists, $\mathrm{PhDs}$ and students in the analysis of managing development in enterprise employees in volatile conditions, as well as for a broad range of people interested in organization and business development.

In the light of the above, I would like to recommend this monograph for publication by a scientific journal.

\section{REVIEWER:}

\section{Elżbieta JĘDRYCH}

Doctor of Economic Sciences, Professor,

Department of Economics, Management and Commercial activities of Academy of Finance and Business Vistula, Warsaw, Poland

Director of the Science and Research Center AFiB Vistula

ORCID ID: 0000-0002-8526-2776 